\title{
EVALUATION OF ACUTE TOXICITY AND ANTI- INFLAMMATORY ACTIVITY OF CALLUS EXTRACTS OF PULICARIA INCISA (LAM.) DC.
}

\author{
ROUANE, A. ${ }^{1,2^{*}}-$ CHABANE, $D .{ }^{1}-$ ARAB, K. $^{2}$ \\ ${ }^{1}$ Research Laboratory on Arid Zones (LRZA), Faculty of Biological Sciences, University of Sciences \\ and Technology Houari Boumediene, PB, N³2 El Alia, Bab Ezzouar, 16111 Algiers, Algeria \\ ${ }^{2}$ Laboratory of Valorization and Conservation of Biological Resources (VALCOR), Department of \\ Biology, Faculty of Sciences, University M'hamed Bougara of Boumerdes, 35000 Boumerdes, Algeria \\ *Corresponding author \\ e-mail: rouaneasma@yahoo.fr; phonelfax:+213-21-639-141
}

(Received $3^{\text {rd }}$ Sep 2018; accepted $5^{\text {th }}$ Nov 2018)

\begin{abstract}
This study was aimed to investigate the effect of bioactive molecules of callus infusion of Pulicaria incisa (Lam.) DC, by the evaluation of anti-inflammatory activity and acute toxicity. $70 \%$ was the higher rate of callus obtained from young capitula cultivated on Murashige and Skoog (1962) (MS) solid medium containing $2.4 \mathrm{D} 4.10^{-5} \mathrm{M}$ and KIN $5.10^{-6} \mathrm{M}$ for 4 months. A Phytochemical screening based on colorimetric reactions was performed on the callus infusion material. Unlike the absence of primary components (starch, reducing sugars), secondary metabolites such as mucilage, saponins, flavonoids and anthocyanins were revealed. No sign of toxicity was observed by the application of 0.25 to $5 \mathrm{~g} / \mathrm{kg}$ doses in this investigation, although, a significant anti-inflammatory response was revealed at $5 \mathrm{~g} / \mathrm{kg}$ compared to that of Diclofenac ${ }^{\circledR}$. The chromatographic analysis (HPLC) detected the presence of 3-hydroxy-4methoxycinnamic acid the main phenolic acid produced by callus, which could be responsible of the positive anti-inflammatory reaction. These findings suggest that the callus could be an alternative source of bioactive metabolites useful in the human health as an anti-inflammatory source.
\end{abstract}

Keywords: Pulicaria incisa (Lam.) DC., Asteraceae, Tamanrasset, callus infusion, bioactive metabolites, biological effects

\section{Introduction}

Pulicaria incisa (Lam.) DC., (Asteraceae) called "Tamayout" or "Ameo" is an endemic aromatic and medicinal herb with golden yellow capitula (flowers) rich in flavonoids and phenolic compounds (Ewais et al., 2014). It is traditionally used by aboriginal people "touaregs" in southern Algeria (Tamanrasset) to treat human pains as flu, fever, coughs, diabetes, palpitations (Maiza, 2008) and also to relieve carminative and anti-inflammatory troubles (Boumaraf et al., 2016). Scientific available studies reported the presence of several metabolites which could have a role in these healing reactions such as sesquiterpene lactones (Ghouila et al., 2009), the flavonoids (Mansour et al., 1990) and the caryophyllene derivatives (San Feliciano et al., 1989). Face to the common use of this aromatic and medicinal plant (PAM) by aboriginal population and healers by its "random-harvesting" without any ecological preservation measurement and the climate changes as rainfall less, soil salinization (Rouane, 2012), the number of "plant feets" is being less and less accessible.

Note that, some of endemic plant species in this Saharan area of Algeria early known for its rich flora are currently disappeared by these problems (Nacer bey et al., 2015). To ovoid this current critical situation, tissue culture techniques are being as alternative pathway to obtaining new plant material as callus and cell suspension considered as source for 
bioactive component production (Eid and Metwally, 2017). To our knowledge, there is no publication thus on the formation of callus with the secondary metabolites contents before and after callus establishment on this Asteraceae. This manuscript presents the results of the evaluation of a therapeutic power of aqueous extract from callus 4-months by performing chemical screening followed by the determination of the $\mathrm{LD}_{50}$ and the anti-inflammatory activity test on mice.

\section{Materials and methods}

\section{Plant material and callus induction}

The fresh young-inflorescences of Pulicaria incisa Lam. (DC.) were harvested in March 2013, in natural area of Ahaggar Tamanrasset, Latitude: $22^{\circ} 47^{\prime} 13^{\prime \prime}$ North, Longitude: $5^{\circ}$ $31^{\prime} 38^{\prime \prime}$ East, Altitude: $1470 \mathrm{~m}$ ), recognized according to the plant features by using the flora (Ozenda, 2004) and the book entitled The Hoggar, botanical trip (Sahki and Sahki, 2004), confirmed by the botanists of National Institute of Forest Research "INRF" of Tamanrasset (Tam). The Specimen voucher was deposited in National Herbarium of the Research laboratory of Arid Zones LRZA Herbarium for authentication (N²-2012 Tam; PAM/LRZA/USTHB).

After isolation, natural capitula of $8 \mathrm{~mm}$ diameter were freshly taken, then, sterilized in Mankooza solution $(0.01 \%)$ for $30 \mathrm{~min}$, well rinsed, thus, immersed in mercuric chloride $\mathrm{HgCl}_{2}(0.01 \%)$ for $10 \mathrm{~min}$ and rinsed with sterile distilled water 3 times of $5 \mathrm{~min}$ each. The capitula were, dried and cultivated on Murashige and Skoog (1962) medium supplemented with $2 \mathrm{~mL}$ Morel and Wetmore vitamins (1955), 3\% (w/v) sucrose $\left(30 \mathrm{~g} \mathrm{~L}^{-1}\right), 0.8 \%(\mathrm{w} / \mathrm{v})$ agar $\left(8 \mathrm{~g} \mathrm{~L}^{-1}\right)$ and different growth regulators combinations and concentrations (Table 1). The medium was adjusted to $\mathrm{pH} 5.8$ and autoclaved at $120{ }^{\circ} \mathrm{C}$ for $20 \mathrm{~min}$. The cultures were incubated at $27 \pm 1^{\circ} \mathrm{C}$ in total darkness until callus induction and high multiplication. The application of hormone (growth regulators) concentrations and combinations were chosen as treatment to express the morphogenetic capacities of the explants (Chabane, 2007; Rouane, 2012).

Table 1. Different media composition in Auxin-cytokinin concentrations tested

\begin{tabular}{c|c|c|c|c|c}
\hline \multirow{2}{*}{ Media } & \multicolumn{5}{|c}{ Auxins/Cytokinins (mole/L) } \\
\cline { 2 - 6 } & $\mathbf{2 . 4 D}$ & NAA & IAB & BAP & KIN \\
\hline Control & \multicolumn{5}{|c}{ None } \\
\hline M1 & $5.10^{-4}$ & - & - & $4.10^{-6}$ & - \\
M2 & $3.10^{-5}$ & - & - & - & $5.10^{-6}$ \\
M3 & $4.10^{-5}$ & - & - & - & $5.10^{-6}$ \\
M4 & - & $5.10^{-6}$ & $4.10^{-6}$ & $3.10^{-4}$ & $5.10^{-6}$ \\
\hline
\end{tabular}

2.4 D: 2.4-dichlorophenoxyacetic acid, NAA: naphthalene acetic acid, IAB: Indole butyric acid, BAP: 6-benzylaminopurine, KIN: kinetin

\section{Preparation of infusion extracts}

Two types of infusion extracts were prepared, in boiled water (for phytochemical screening analysis) and in $\mathrm{NaCl}(0.9 \%)$ for bioactivity tests (anti-inflammatory and acute toxicity). 
$5 \mathrm{~g}$ of each, callus (fresh) and natural capitula (young flowers, air-dried and chopped) were separately soaked in $100 \mathrm{~mL}$ of boiled solution for $20 \mathrm{~min}$, then filtered through Wathman filter paper (Cat $\left.\mathrm{N}^{\circ} 40,1440-110\right)$, the filtrate obtained was used. Note that, natural capitula were only used in phytochemical screening to determine the overall chemical composition of callus obtained by in vitro culture assays.

\section{Animal preparation}

Albino mice Mus musculus (20-30 g weight intervals, 10-12 weeks-old) under temperature of $22-24{ }^{\circ} \mathrm{C}, 50 \%$ humidity, $12 \mathrm{~h}$ photoperiod, feeded by pellets scheme and tap water ad libitum were chosen. The Statement of safety was approved by the ethical committee of (CRD-SAIDAL, Algiers).

\section{Biochemical composition}

\section{Phytochemical screening}

Callus and natural capitula infusions were separately treated with various solvents (Table 2) to detect the different bioactive components by colorimetric or precipitation reactions as shown in Table 2 (Harborne, 1998; Bruneton, 2009).

Table 2. Phytochemical screening of natural capitula and callus infusion

\begin{tabular}{|c|c|c|c|}
\hline \multicolumn{2}{|c|}{ Compounds } & Chemical reagents & Colorimetric reactions \\
\hline $\begin{array}{c}\text { Primary } \\
\text { metabolites }\end{array}$ & $\begin{array}{c}\text { Reducing sugars } \\
\text { Starch } \\
\text { Glucosides }\end{array}$ & $\begin{array}{c}\text { Fehling liquor } \\
\text { Iode }\left(\mathrm{I}_{2}\right) \\
\mathrm{H}_{2} \mathrm{SO}_{4}\end{array}$ & $\begin{array}{l}\text { Orange precipitation } \\
\text { Purple blue } \\
\text { Orange-red-purple }\end{array}$ \\
\hline \multirow{7}{*}{$\begin{array}{l}\text { Secondary } \\
\text { metabolites }\end{array}$} & Mucilages & Ethanol & Flaky precipitate \\
\hline & Flavonoids & $\begin{array}{c}\mathrm{HCl}+\text { Magnesium chips }(\mathrm{Mg}) \\
+ \text { Isoamelic alcohol }\end{array}$ & Orange-red \\
\hline & Anthocyanins & $\begin{array}{c}\mathrm{HCl} \\
\text { Ammonia } 1 / 2\end{array}$ & $\begin{array}{l}\text { Red } \\
\text { Blue }\end{array}$ \\
\hline & Total tannins & $\mathrm{Fe} \mathrm{Cl}_{3} 5 \%$ & Blue black \\
\hline & Catechic tannins & Stiansy reagent (formol+HCl) & Red \\
\hline & Saponins & $\mathrm{NaOH} 0.1 \mathrm{~N} / \mathrm{HCl} 0.1 \mathrm{~N}$ & Foam formation \\
\hline & Iridoids & $\mathrm{HCl} /$ heating & Blue \\
\hline
\end{tabular}

$\mathrm{NaOH}$ : sodium hydroxide, $\mathrm{HCl}$ : hydrogen chloride, $\mathrm{FeCl}_{3}$ : ferric chloride, $\mathrm{H}_{2} \mathrm{SO}_{4}$ : sulfuric acid

\section{High-performance liquid chromatography analysis (HPLC)}

High-performance liquid chromatography (HPLC) was carried out with a Agilent 1100 System, quaternary pump, on-line degasser automatic injector and UV detector with bars of diodes surveyor (DAD), using Hypersil BDS-C18 column $(250 \times 4.6 \mathrm{~mm}$, $5 \mu \mathrm{m})$ at $30{ }^{\circ} \mathrm{C}$. The chromatographic data system was controlled by the mobile phase (acetic acid $0.2 \% / \mathrm{ACN}$ ) for $30 \mathrm{~min}$. The solvent flow rate was $1 \mathrm{~mL} / \mathrm{min}$.

\section{Biological activities of callus infusion}

The bioactivity determination by two tests (anti-inflammatory and acute toxicity) concerns the application of callus infusion on animal models chosen. 


\section{Acute toxicity test}

The examination of acute toxicity was performed in oral gavage as prescribed by Litchfield and Wilcoxon (1949). A total of 5 mice (20-30 g) in separated cages of each group; (control group and 5 experimental groups) were fasted $18 \mathrm{~h}$ before experiment. An oral gavage of $0.5 \mathrm{~mL}$ of callus infusion was administered as follows; $0.25 \mathrm{~g} / \mathrm{kg}$, $0.5 \mathrm{~g} / \mathrm{kg}, 1 \mathrm{~g} / \mathrm{kg}, 2 \mathrm{~g} / \mathrm{kg}$ and $5 \mathrm{~g} / \mathrm{kg}$, while the control animals were received the $\mathrm{NaCl}$ $(0.9 \%) . \mathrm{NaCl}$ expresses the physiological water $0.9 \%$ without any risk, was used for the preparation of different extracts (control and treatments) under the same conditions. The mice were monitored from $30 \mathrm{~min}$ to $4 \mathrm{~h}$. The body weight variation, general behavioral and toxicity symptoms were noted at least once daily for 14 days (Nana et al., 2011). The $\mathrm{DL}_{50}$ and the maximum dose without effect (MDE) were calculated and compared to the control batch.

\section{Evaluation of carrageenan-induced anti-inflammatory activity}

The anti-inflammatory activity of callus extracts of Pulicaria incisa was performed using inflammation by edema formation induced by carrageenan on hind-paw of mice (Winter et al., 1962). Four groups of 10 male mice in each (20 to $30 \mathrm{~g}$ ) were fasted $18 \mathrm{~h}$ before the beginning of the experiment. A dose of $0.5 \mathrm{~mL}$ was orally given as follows; control group ( $\mathrm{NaCl} 0.9 \%$ ), experimental groups by callus infusion at $2 \mathrm{~g} / \mathrm{kg}(\mathrm{I}), 5 \mathrm{~g} / \mathrm{kg}$ (II) and Diclofenac ${ }^{\circledR}$ at $5 \mathrm{mg} / \mathrm{kg}$ (experimental group III). $30 \mathrm{~min}$ after each administration, $25 \mu \mathrm{L}$ of the $1 \% \mathrm{w} / \mathrm{v}$ carrageenan was injected subcutaneously into the plantar aponeurosis of the left hind paw of each mouse. The behavior and responses of all mice were observed and noted (Zhang et al., 2015). Three hours later, the animals were quickly sacrificed. The variation of paw volume of each animal was noted, then, the mean of weight $(\mathrm{M})$ for each group was calculated. The following equations (Eqs. 1-2) were used to calculate the percentages of the edema $(\% \mathrm{E})$ and of edema reduction (\% E.R) respectively:

$$
\begin{gathered}
\% \mathrm{E}=\frac{(\mathrm{M} \mathrm{LPW}-\mathrm{M} \mathrm{RPW})}{\mathrm{M} \mathrm{RPW}} \times 100 \\
\% \text { E.R. }=\frac{(\% \mathrm{E} \mathrm{PC}-\% \mathrm{E} \mathrm{PE})}{\% \mathrm{E} \mathrm{PC}} \times 100
\end{gathered}
$$

where: \% EPC: percentage of edema of the paw of the control, \% EPE: percentage of edema of the paw of the experimental groups, LPW: Left Paw Weight, RPW: Right Paw Weight, M: Mean of weights.

\section{Statistical analysis}

The results obtained were analyzed using Statistica Software (6.0). Data were expressed as means $\pm \mathrm{ESM}$ (or means $\pm \mathrm{SD}$ ), then were subjected to One way analysis of variance (ANOVA) followed by Duncan Multiple Range Test (DMRT) and differences between data means were regarded statistically significant at $\mathrm{P}<0.01$ and $\mathrm{P}<0.05$ (Duncan et al., 1977). 


\section{Results}

\section{Callus induction}

This study showed that the young capitula reacted positively onto media tested with 30 to $70 \%$ callus induction ratios; M2 (2.4D $\left.3.10^{-5} \mathrm{M} / \mathrm{KIN} 5.10^{-6} \mathrm{M}\right)$ with $60 \%$ and M3 $\left(2.4 \mathrm{D} 410^{-5} \mathrm{M} / \mathrm{KIN} 5.10^{-6} \mathrm{M}\right)$ with $70 \%$ compared to that of M4 (NAA-IAB/BAP-KIN) with $30 \%$ (see Fig. 1, Table 3).
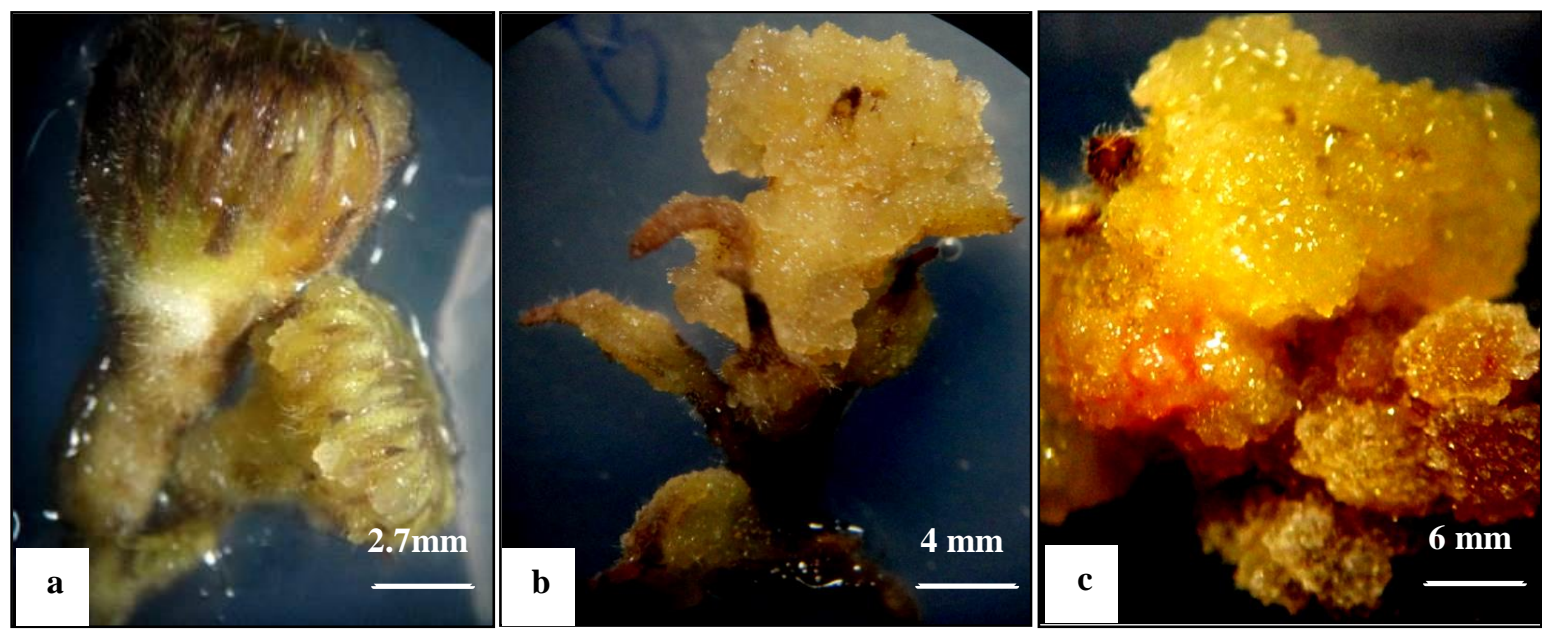

Figure 1. Callus induction and multiplication of capitula explants of Pulicaria incisa on culture media (M 3). a Induction after 2 weeks, $\boldsymbol{b}$ friable callus formation after 4 weeks, $\boldsymbol{c}$ callus multiplication after 6 weeks

Nevertheless, no callus was observed onto M1 (2.4D/BAP) even the long maintenance of explants (32 weeks). The M3 is thus, considered the most successful of callus formation in this experiment. The color and morphological aspects of calluses varied with time and the concentrations of growth regulators. All callus masses obtained were friable with variable multiplication degree (low, middle and high) from 40 to $80 \mathrm{~mm}$ diameter.

Table 3. Callus induction frequency (\%) from Pulicaria incisa young capitula after several weeks of culture

\begin{tabular}{l|c|l|c|c}
\hline \multicolumn{1}{c|}{ Media Aux/Cyto } & Call. (\%) & Call. col. morph. & Degr. call. form. & W. cult. \\
\hline Control & 0 & None & - & 32 \\
\hline M1: 2.4D/BAP & 0 & $\begin{array}{l}\text { None } \\
\text { Mriable, yellowish, } \\
\text { whitish to brown }\end{array}$ & + ++ & 32 \\
M2.4 D/KIN & 60 & $\begin{array}{l}\text { Friable, yellowish to } \\
\text { whitish brown } \\
\text { Friable, whitish to } \\
\text { brown }\end{array}$ & +++ & 2 \\
M3: 2.4 D/KIN & 30 & + & 6 \\
M4: NAA, IAB/BAP, KIN & 70 & \\
\hline
\end{tabular}

+: poor, ++: moderate, +++: profuse, Aux/Cyto: (Auxins/Cytokinins) combinations, 2.4 D: 2.4dichlorophenoxyacetic acid, NAA: naphthalene acetic acid, IAB: indole butyric acid, BAP: 6benzylaminopurine, KIN: kinetin, Call. (\%): Callus percentage, Call. col. morph: Callus color morphology, Degr. call. form: degree of callus formation, W. cult.: weeks of culture 
The degree of callus formation expresses the variation of number and diameter of callus mass by capitula with time; + : low with diameter $(\mathrm{d}<40 \mathrm{~mm})$, ++ : middle $(40 \mathrm{~mm}<\mathrm{d}<60 \mathrm{~mm})$, +++ : higher $(60 \mathrm{~mm}<\mathrm{d}<80 \mathrm{~mm})$. The most important callus mass (diameter, $80 \mathrm{~mm}$ ) was observed on $2.4 \mathrm{D}-\mathrm{KIN}$ that on media added of NAA-IAB or BAP-KIN after 4 months.

\section{Biochemical compounds of infusion extracts}

\section{Qualitative biochemical composition}

The phytochemical screening has mentioned a total absence of primary metabolites (glucosides and starch) with the presence of secondary metabolites.

Table 4 summaries the variation of phytochemical compounds of callus infusion compared to that of natural capitula, callus infusion showed the total absence (-) of primary metabolites (glucosides, reducing sugars, and starch), the presence of secondary metabolites. On the other hand, natural capitula infusion revealed the presence of glucosids, flavonoids, mucilages, tannins, cathechical tannins and prints of anthocyanins. Note that, the amount of each varied from a weak (+) to important (+++). The comparison between callus and natural capitula infusion exposed a large amount of mucilage in callus, a middle content in both, of saponins and anthocyanins with a total absence to middle amount of Glucosids, Iridoids and tannins.

Table 4. Phytochemical composition of callus and natural capitula

\begin{tabular}{c|c|c|c}
\hline & Compounds & Callus & Natural capitula \\
\hline \multirow{2}{*}{ Primary } & Starch & - & - \\
metabolites & Reducing sugars & - & - \\
& Glucosides & - & ++ \\
\hline \multirow{5}{*}{ Secondary } & Mucilages & +++ & + \\
metabolites & Saponins & ++ & ++ \\
& Flavonoids & + & ++ \\
& Anthocyanins & + & + \\
& Total Tannins & - & ++ \\
& Catechic Tannins & - & ++ \\
& Iridoids & - & - \\
\hline
\end{tabular}

-: total absence, + : weak amount, ++: middle amount, +++: important amount

\section{Chromatographic analyses by HPLC}

The comparison of samples tested to all standards used revealed a moderate 3hydroxy-4-methoxycinnamic acid content, considered as the main phenolic acid in callus infusion assay with $3.159 \%$ (peak area percent) recorded at $\lambda=260 \mathrm{~nm}$ (see Fig. $2 a, b$ ).

\section{Biological activities evaluation of callus}

\section{Oral acute toxicity study and body weight variation}

The weighting of all animals recorded an increase of body weight of mice in all control and assays tested with time (see Fig. 3). The callus infusion tested on mice 
orally at various doses $(0.25 \mathrm{~g} / \mathrm{kg}, 0.5 \mathrm{~g} / \mathrm{kg}, 1 \mathrm{~g} / \mathrm{kg}, 2 \mathrm{~g} / \mathrm{kg}$ and $5 \mathrm{~g} / \mathrm{kg})$ did not toxic, neither mortality was observed after two weeks of application. Note that, $5 \mathrm{~g} / \mathrm{kg}$ was the maximum dose without effect (MDE) compared to the control batch. Duncan Multiple Range Test (DMRT) revealed a higher significant difference of the body weight between control and all doses tested at 15 days of treatment $\left(\mathrm{P}^{* * *}<0.001\right)$.

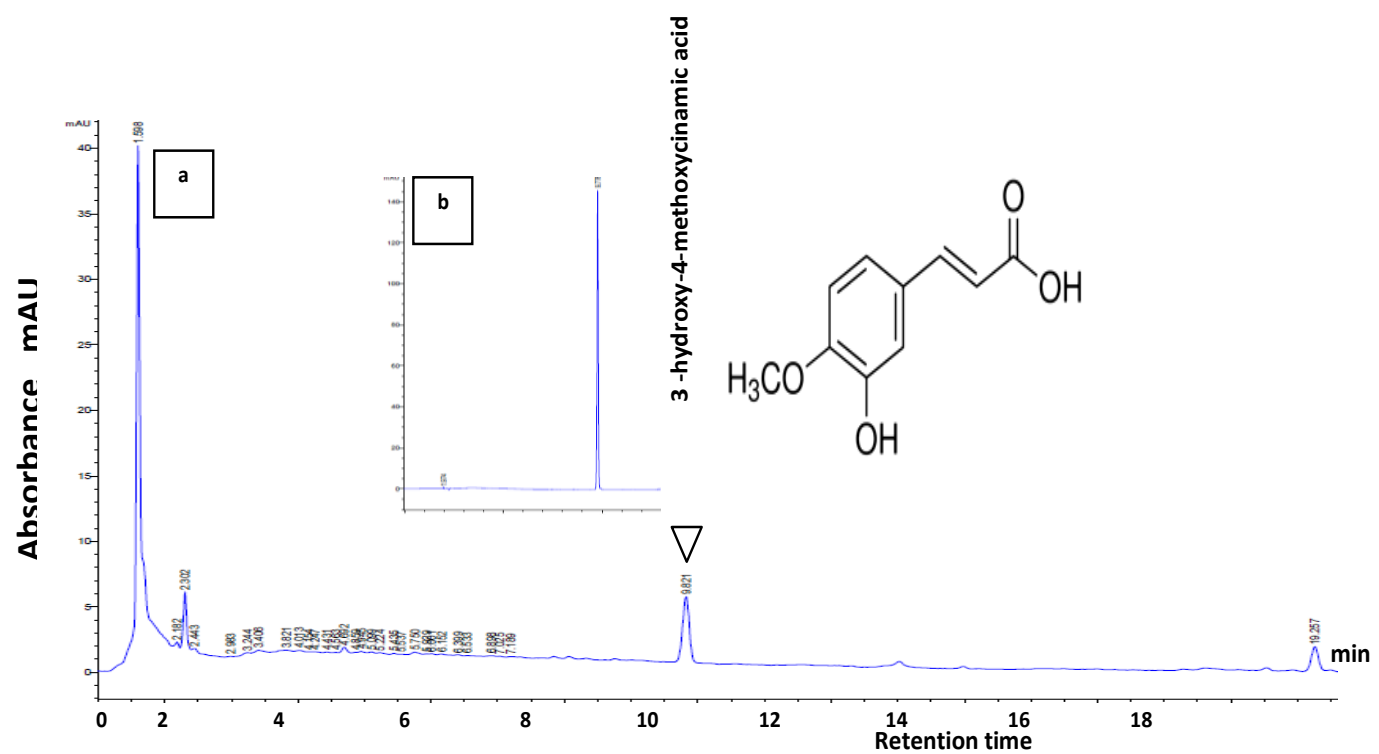

Figure 2. HPLC chromatogram. a Callus infusion of Pulicaria incisa (Lam.) DC., visualized at $\lambda=260 \mathrm{~nm} ; \boldsymbol{b}$ 3-hydroxy-4-methoxycinnamic acid Standard phenolic acid injected in the same conditions

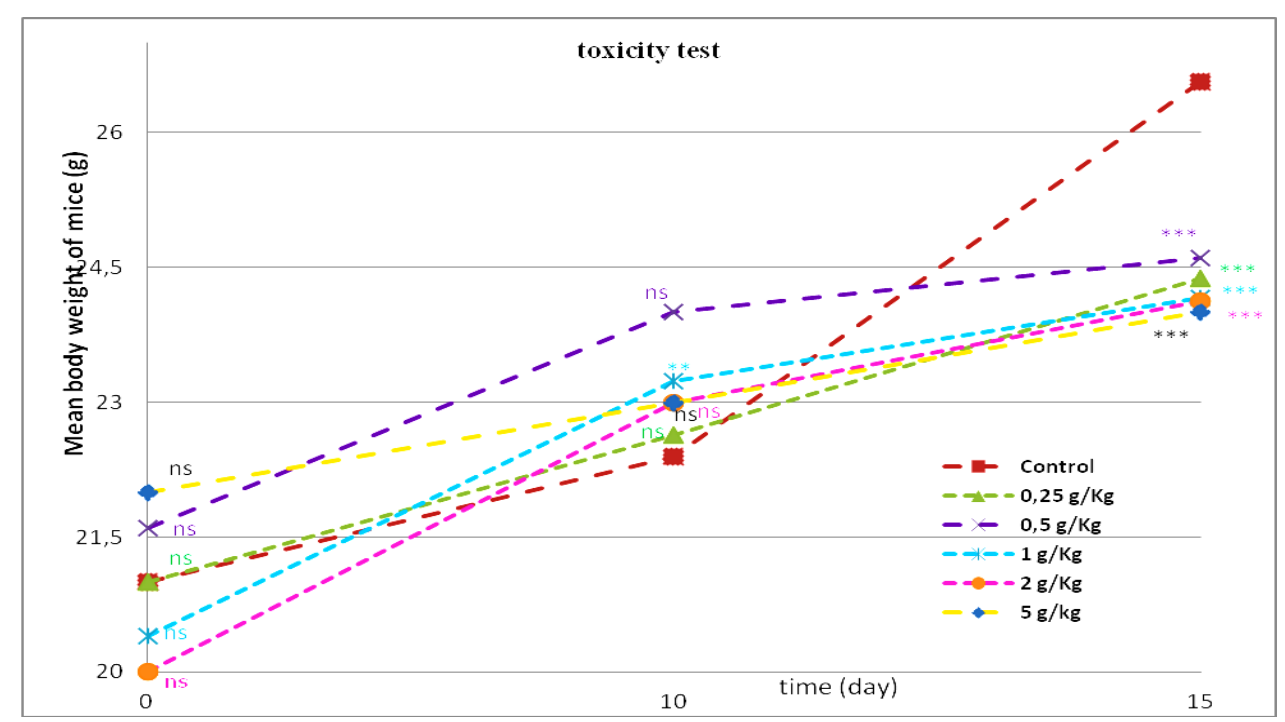

Figure 3. Body weight variation with time of callus infusion treatment compared to the control. Means (means \pm standard error). Duncan Multiple Range Test (DMRT), expressed differences of data means *** indicate a higher significant difference between the control and treatment $(* * * P<0.001), * * P<0.01$ : very significant, $n$ s not significant 


\section{Anti-inflammatory activity evaluation}

The anti inflammatory activity of callus infusion was investigated. As shown in Table 5 and Figure 4, the monitored of weight of mice of all groups showed a decrease of the paw edema, of $37.66 \%$ (at $2 \mathrm{~g} / \mathrm{kg}$ ), 46.95\% (at $5 \mathrm{~g} / \mathrm{kg}$ ) by callus infusion and $40.65 \%$ by the Diclofenac ${ }^{\circledR}$. Duncan Multiple Range Test (DMRT) revealed a significant difference between the control compared to experimental group at $5 \mathrm{~g} / \mathrm{kg}$ dose and the Diclofenac ${ }^{\mathbb{B}}\left(\mathrm{P}^{*}<0.05\right)$.

Table 5. Comparison of edema reactions (edema apparition and reduction) in mice treated with Diclofenac ${ }^{\circledR}(5 \mathrm{mg} / \mathrm{kg})$ and with callus infusion

\begin{tabular}{|c|c|c|c|c|c|}
\hline \multicolumn{6}{|c|}{ Anti-inflammatory test, $\mathrm{n}=10$} \\
\hline \multirow[b]{3}{*}{ Doses } & \multirow[b]{2}{*}{$\begin{array}{c}\text { Control group } \\
\mathrm{NaCl}\end{array}$} & \multicolumn{3}{|c|}{ Experimental groups } & \multirow{3}{*}{$\begin{array}{c}\text { ANOVA one } \\
\text { way }\end{array}$} \\
\hline & & $\begin{array}{l}\text { Callus infusion } \\
\text { (I) }\end{array}$ & $\begin{array}{c}\text { Callus infusion } \\
\text { (II) }\end{array}$ & $\begin{array}{c}\text { Diclofenac }^{\circledR} \\
\text { (III) }\end{array}$ & \\
\hline & $0.9 \%$ & $2 \mathrm{~g} / \mathrm{kg}$ & $5 \mathrm{~g} / \mathrm{kg}$ & $0.005 \mathrm{~g} / \mathrm{kg}$ & \\
\hline M. LPW & $0.1831 \pm 0.007$ & $0.1699 \pm 0.004$ & $0.1678 \pm 0.0041^{*}$ & $0.1623 \pm 0.003 *$ & $\begin{array}{c}P 0.027 \\
* \mathrm{P}<0.05\end{array}$ \\
\hline M. RPW & $0.1263 \pm 0.004$ & $0.1327 \pm 0.003$ & $0.1355 \pm 0.0035$ & $0.1281 \pm 0.002$ & $\begin{array}{l}P 0.197 \\
P>0.05\end{array}$ \\
\hline$\% \mathrm{E}$ & $45 \pm 0.036$ & $28 \pm 0.022$ & $24 \pm 0.021 *$ & $27 \pm 0.017^{*}$ & \\
\hline$\% \mathrm{ER}$ & I & 37.66 & 46.95 & 40.65 & \\
\hline
\end{tabular}

LPW: Left Paw Weight, RPW: Right Paw Weight, \%E: percentage of edema, \% ER: percentage of edema reduction, Mean \pm SEM: M Mean; \pm SEM: standard error of means, $\mathrm{n}=10$ : total mice in group tested, ${ }^{\circledR}$ : Reference, ${ }^{*} \mathrm{P}<0.05$ : compared to control, was considered significant by the Duncan Multiple Range Test (DMRT)

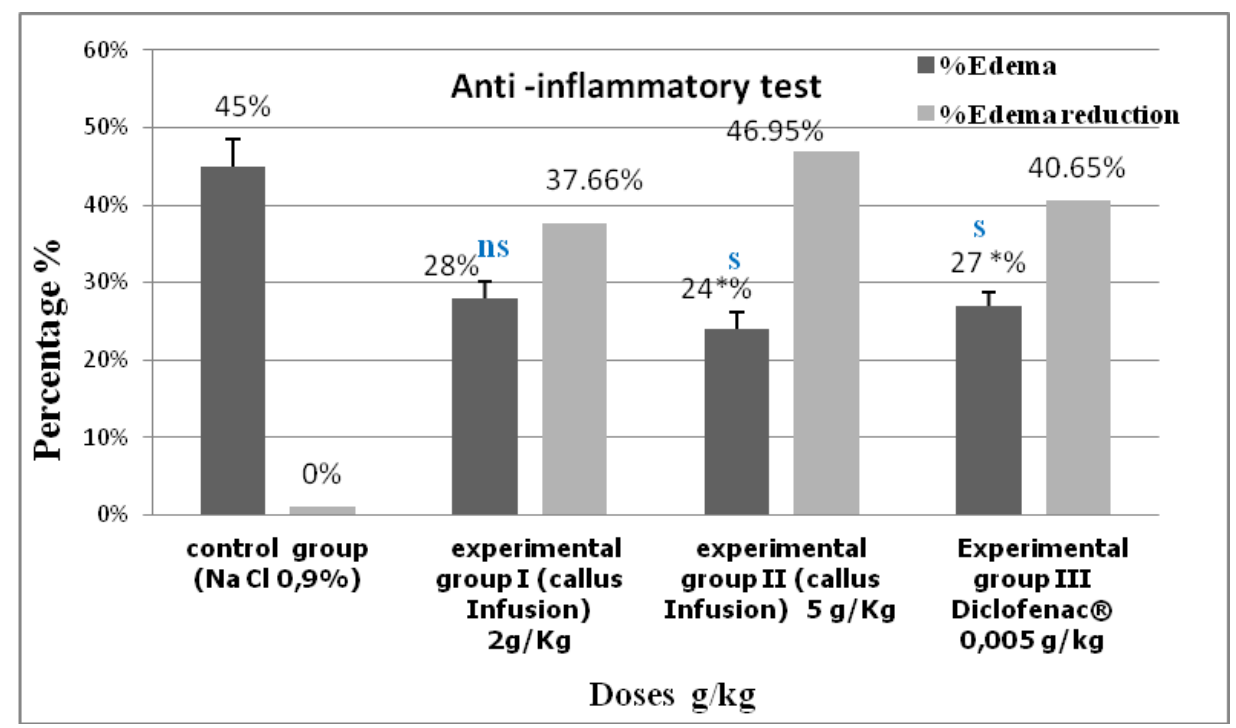

Figure 4. Anti-inflammatory activity evaluation (\%, mean \pm SEM) of callus infusion (2 and $5 \mathrm{~g} / \mathrm{kg}$ ) compared to Diclofenac ${ }^{\circledR}(5 \mathrm{mg} / \mathrm{kg}$ ) and control treatment. Means (means \pm standard error). The values of Duncan Multiple Range Test (DMRT), expressed with a letter "s" a significant difference between the control compared to experimental group at $5 \mathrm{~g} / \mathrm{kg}$ dose and the reference (Diclofenac $\left.{ }^{\circledR}\right)$, with $P^{*}<0.05$; ns: not significant 


\section{Discussion}

The influence of different concentrations and combinations of growth regulators on the induction of callus from capitula of Pulicaria incisa showed a better response in the medium supplemented with 2,4D and KIN. $70 \%$ was the higher callus rate obtained onto 2.4D $4.10^{-5} \mathrm{M}$ and KIN $5.10^{-6} \mathrm{M}$. The same observations have been noted by Gupta et al. (2015) and Farvardin et al. (2017) who confirmed the effectiveness of 2.4D/KIN in vitro conditions by the best induction and proliferation of callus masses in dicotyledonous plants.

However, capitula cultivated on $2.4 \mathrm{D} / \mathrm{BAP}$, did not display any change in their morphological aspects except the total necrotic reaction due to the release of phenolic compounds (Ozyigit et al., 2007); which have generally a negative effect by the inhibition of enzyme functions and the inactivation of explants growth leading browning and darkening of the media (Arnaldos et al., 2001).

Because, the weak amount of anthocyanins in callus is similar to that of capitula, this suggests that dark has no influence upon action of their biogenesis, thus, it is advised to carry out further experiments by exposure of callus under light to boost the biosynthesis process. The same suggestions were previously supposed by Mathur et al. (2010) on callus line of Panax sikkimensis Ban. (Araliaceae). Also the total absence of starch and reducing sugars indicates that the plant do not synthesize or store starch. That's in agreement with Benhouhou (2005) regarding the presence of "Inulin" in Pulicaria incisa Inuleae tribe. However, the highest production of mucilage in callus could be a secondary energy reserve (Langenheim, 2003). Currently, Gupta et al. (2015) advise to harmonize the combinations of growth regulators to ensure the high production of mucilage under in vitro conditions. Further experiments are useful to run cultures under light conditions for the possible high secondary metabolites amounts production.

Regarding the HPLC analysis, 3-Hydroxy-4-methoxycinnamic acid, was appeared to be the main phenolic acid in callus infusion, this result is consistent with the findings of Arafa et al. (2015) and Azeez et al. (2017). These authors have reported that it is the major compound of callus produced under in vitro conditions.

In the current study, the weighting of animals recorded an increase of body weight of mice in all control and assays tested with time; it was expressed by the moderate gaining of weight. Conversely, Jahn and Günzel (1997), also Saad et al. (2016) described the toxicity sign by the weight loss. We consider that, saponins, mucilages, anthocyanins and flavonoids of callus are without any toxic prints on mice (Avachat et al., 2011; Du et al., 2015; Muthukumaran et al., 2017). Note that Hammiche and Maiza (2006) have not scored any toxic effect of Pulicaria incisa in the field findings.

The moderate anti-inflammatory activity of the callus infusion registered, could be explained by the presence of 3-hydroxy-4-methoxycinnamic isoferulic acid detected at $260 \mathrm{~nm}$ ). Our results are in agreement with reports of Shiraki et al. (1998) and Kim et al. (2012), who displayed that the 3-hydroxy-4-methoxycinnamic acid has both antipyretic and anti-inflammatory activities by suppressive of interleukin-alpha compounds production. In addition, the calm state of mice during the experiments was certainly due to the higher amount of mucilage in callus, the polysaccharides, which has softening and anti-inflammatory activities, reducing inflammation (Morrow, 1998; Sindhu et al., 2012). Also, the mucilage richness of callus infusion suggests the soothe effect of inflamed tissues. We suggest that the flavonoids and anthocyanins content in the callus could apply an anti-inflammatory effect. Wiseman et al. (2001) and O'Leary et al. (2004) explained that flavonoids exert multi-level anti-inflammatory properties by 
the inhibition of the production of inflammatory cytokines. In parallel, Larrosa et al. (2010) and Havsteen (2002) have reported the synergetic important role of flavonoids and anthocyanins in the protection of veins and capillaries. Moreover, Ez Zoubi et al. (2016) underlined the significant anti-inflammatory effects of flavonoids and mucilage fractions with time on edema especially on cycloxygenase activity (COX) at the later phase by inhibition. We suppose that saponins of callus infusion act as inhibitors of prostaglandins to increase the anti-inflammatory response.

This study highlighted the successful callus induction using capitula explants and culture conditions chosen, this new material (calluses) provide a higher production of mucilage comparing to mother plant. This overview opens the minds to their use as cell cultures for the production of these active components.

These findings have also successfully showed the effective therapeutic potential of callus to consider in further biological activities. Indeed, the application of callus infusion at ( 2 and $5 \mathrm{~g} / \mathrm{kg}$ ) on animal models has revealed an interesting antiinflammatory effect comparing to Diclofenac ${ }^{\circledR}$, due to the production of 3-hydroxy-4methoxycinnamic acid and other components.

\section{Conclusion}

This study reports for the first time the callus formation of Pulicaria incisa and evaluation of the anti-inflammatory activity due to its biological composition. Based on our results, we have successfully showed an interactive relationship between the pharmacology and the plant biotechnology which could be applying into the large-scale active principles production in the future. In addition, these findings suggest that the callus extracts has a positive oral safety, which is non-toxic, may be useful in human health by anti-inflammatory effects. These effects could be ascribed to phenolic compounds such as 3-hydroxy-4-methoxycinnamic as anti-inflammatory source with markedly reduce edema. Thus, future studies are needed to induce the production of high secondary metabolites amounts in calluses mass, by varying elicitors and medium composition, then, should examine the major components isolated individually after identification by HPCL. The application of this process on other endemic medicinal plants could be more advantageous for metabolites production and brittle plant species preservation independently of current ecological conditions.

Acknowledgements. This study was supported by General Direction of Scientific Research and Technological Development (DGRSDT) with the High Ministry of Research and Study (MESRS) of Algiers. We express our deepest thanks to Pr N. Bouguedoura (LRZA, USTHB), Pr A. Mohammedi (VALCOR) Boumerdes, Dr. K. Azine of Pharmaco-toxicology of CRD Saidal and Z. Bettache of Central Laboratory of Scientific Police (Algiers) for their cooperation.

\section{REFERENCES}

[1] Arafa, N. M., Ibrahim, M. M., Aly, U. I. (2015): Evaluation of total phenolic contents and antioxidant activity of carrot callus extracts as affected by phenylalanine precursor. Plant Tissue Culture and Biotechnology 25: 207-221.

[2] Arnaldos, T. L., Muñoz, R., Ferrer, M. A., Calderonn, A. A. (2001): Changes in phenol contents during strawberry (Fragaria ananassa cv. Chandler) callus culture. - Physiolgia Plantarum 113: 315-333. 
[3] Avachat, A. M., Dash, R. R., Shrotriya, S. N. (2011): Recent investigations of plant based natural gums, mucilages and resins in novel drug delivery systems. - Indian Journal of Pharmaceutical Education and Research 45: 86-99.

[4] Azeez, H., Ibrahim, K., Pop, R., Pamfil, D., Hârţa, M., Bobiș, O. (2017): Changes induced by gamma ray irradiation on biomass production and secondary metabolites accumulation in Hypericum triquetrifolium Turra callus cultures. - Industrial Crops and Products 108: 183-189.

[5] Benhouhou, S. A. (2005): Guide to Medicinal Plants in North Africa: Pulicaria incisa (Lam.) DC. - IUCN, Malaga, Spain.

[6] Boumaraf, F. M., Carbone, M., Letizia Ciavatta, M., Benyahia, S., Ameddah, S., Menad, A. Benayache, S., Benayache, F., Gavagninet, M. (2016): Exploring the bioactive terpenoid content of an Algerian plant of the genus Pulicaria: the ent-Series of Asteris cunolides. - Journal of Natural Products 80: 82-89.

[7] Bruneton, J. (2009): Pharmacognosie, phytochimie, plantes médicinales. - Lavoisier Technique \& Documentation. $4^{\text {éme }}$ ed. Paris.

[8] Chabane, D. (2007): Improvement of date palm (Phoenix dactylifera L). by protoplast fusion of two cultivars Deglet Nour sensitive and Takerboucht resistant to bayoud disease. - Doctorat, USTHB, Algiers, Algeria (in French).

[9] Du, M., Huang, S., Zhang, J., Wang, J., Hu, L., Jiang, J. (2015): Toxicolological test of saponins from Sapindus mukorossi Gaerth. - Open Journal of Forestry 5: 749-753.

[10] Duncan, R. C., Knapp, R. G., Miller, M. C. (1977): Test of Hypotheses in population Means, In: Introductory Biostatistics for Health Sciences. - John Wiley and Son Inc., New York, pp. 71-96.

[11] Eid, H. H., Metwally, G. F. (2017): Phytochemical and biological study of callus cultures of Tulbaghia violacea Harv. Cultivated in Egypt. - Natural Product Research 31: 17171724.

[12] Ewais, E. A., Abd El-Maboud, M. M., Haggag, M. (2014): Studies on chemical constituents and biological activity of Pulicaria incisa subsp. incisa (Asteraceae). Report and Opinion 6: 27-33.

[13] Ez Zoubi, Y., Bousta, D., El Mansouri, L., Boukhira, S., Siham, L., Achour, S., Abdellah, F. (2016): Phytochemical screening, anti-inflammatory activity and acute toxicity of hydro-ethanolic, flavonoid, tannin and mucilage extracts of Lavandula stoechas L. from Morocco. - International Journal of Pharmacognosy and Phytochemical Research 8: 3137.

[14] Farvardin, A., Ebrahimi, A., Hosseinpour, B., Khosrowshahli, M. (2017): Effects of growth regulators on callus induction and secondary metabolite production in Cuminum cyminu. - Natural Produt Research 31: 1963-1970.

[15] Ghouila, H., Beyaoui, A., Jannet, H. B., Hamdi, B., Salah, A. B., Mighri, Z. (2009): Isolation and structure determination of pulicazine, a new sesquiterpene lactone from the Tunisian Pulicaria laciniata (Coss. et Kral.) Thell. - Tetrahedron Letters 50: 1563-1565.

[16] Gupta, M., Kour, B., Kaul, S., Dhar, M. K. (2015): Mucilage synthesis in callus cultures of Plantago ovata Forsk. - National Academy Science Letters 38: 103-106.

[17] Hammiche, V., Maiza, K. (2006): Traditional medicine in Central Sahara: Pharmacopoeia of Tassili N'ajjer. - Journal of Ethnopharmacology 105: 358-367.

[18] Harborne, J. B. (1998): Phytochemical Methods a Guide to Modern Techniques of Plant Analysis ( $3^{\text {rd }}$ ed.), Vol 2. - Chapman and Hall, London.

[19] Havsteen, B. (2002): The bioactivity and medical significance of the flavonoides. Pharmacology and Therapeutics 96: 67-202.

[20] Jahn, A. I., Günzel, P. K. H. (1997): The value of spermatology in male reproductive toxicology: do spermatologic examinations in fertility studies provide new and additional information relevant for safety assessment. - Reproductive Toxicology 11: 171-178.

[21] Kim, E. O., Min, K. J., Kwon, T. K., Um, B. H., Moreau, R. A., Choi, S. W. (2012): Antiinflammatory activity of hydroxycinnamic acid derivatives isolated from corn bran in 
lipopolysaccharide-stimulated Raw 264.7 macrophages. - Food and Chemical Toxicology 50(5): 1309-1316.

[22] Langenheim, J. H. (2003): Plant Resins: Chemistry, Evolution, Ecology and Ethnobotany. - Timber Press, Portland, OR, USA.

[23] Larrosa, M., García-Conesa, M. T., Espín, C., Tomás-Barberán, F. A. (2010): Ellagitannins, ellagic acid and vascular health. - Molecular Aspects of Medicine 31: 513539.

[24] Litchfield, J. T., Wilcoxon, F. (1949): A simplified method of evaluating dose-effect experiments. - Journal of Pharmacology and Experimental Therapeutics 96: 99-113.

[25] Maiza, K. (2008): Pharmacopée traditionnelle saharienne: Sahara algérien. - Thèse de doctorat Ph. D., Université Abou Bakr Belkaid, Algerie.

[26] Mansour, R. M. A., Ahmed, A. A., Melek, F. R., Saleh, N. A. M. (1990): The flavonoids of Pulicaria incisa. - Fitoterapia 61(2): 186-187.

[27] Mathur, A., Mathur, A. K., Gangwar, A., Yadav, S., Verma, P., Sangwan, R. S. (2010): Anthocyanin production in a callus line of Panax sikkimensis Ban. - In Vitro Cellular Developmental Biology - Plant 46: 13-21.

[28] Morel, G., Wetmore, R. M. (1955): Fern callus tissue culture. - American Journal Botany 38: $141-143$.

[29] Morrow, T. (1998): Herbal Compound for Relief of PMS through Menopausal Symptoms. - US Patent 707.

[30] Murashige, T., Skoog, F. (1962): A revised medium for rapid growth and bioassays with tobacco tissue cultures. - Physiologia Plantarum 15: 473-497.

[31] Muthukumaran, M., Indu Priyanka, K. R., Bhaskar, S., Kalpana, B., Dinakar, R. (2017): Novel extraction, characterization and pharmaceutical application of okra mucilage (Abelmoschus esculentus) as a pharmaceutical excipient. - World Journal of Pharmacy and Pharmaceutical Sciences 6: 321-328.

[32] Nacer bey, N., Chabane, D., Abdelkrim, H., Aribi, I. (2015): Traditional herbal medicine in Jijel region, Northeast of Algeria. - Advances in Environmental Biology 9: 54-61.

[33] Nana, H. M., Ngane, R. A., Kuiate, J. R., Mogtomo, L. M., Tamokou, J. D., Ndifor, F., Mouokeu, R. S., Ebelle Etame, R. M., AmvamZollo, P. H. (2011): Acute and sub-acute toxicity of the methanolic extract of Pteleopsis hylodendron stem bark. - Journal of Ethnopharmacology 137: 70-76.

[34] O’Leary, K. A., De Pascual-Tereasa, S., Needs, P. W., Bao, Y. P., O’Brien, N. M., Williamson, G. (2004): Effect of flavonoids and vitamin E on cyclooxygenase-2 (COX-2) transcription. - Mutation Research 551: 245-254.

[35] Ozenda, P. (2004): Flore et végétation du Sahara (3rd ed.). - CNRS, Paris.

[36] Ozyigit, I. I., Kahraman, M. V., Ercan, O. (2007): Relation between explant age, total phenols and regeneration response in tissue cultured cotton (Gossypium hirsutum L.) African Journal Biotechnology 6: 003-008.

[37] Rouane, A. (2012): Ethnobotanic, anatomic and phytochemical reactions studies of Pulicaria incisa (Lam.) DC., a medicinal plant of Tamanrasset to biotechnological expression. - Magister Thesis, University of Sciences and Technology Houari Boumediene. Algeria (in French).

[38] Saad, S., Ouafi, S., Chabane, D. (2016): Anti-inflammatory and acute toxicity evaluation of aqueous infusion extract obtained from aerial parts of Marrubium deserti de NOÉ growing in Algeria. - African Journal of Traditional Complementary and Alternative Medicines 13: 71-539.

[39] Sahki, A., Sahki, R. (2004): Le Hoggar: promenade botanique. - Atelier Ésope, Lyon.

[40] San Feliciano, A., Medarde, M., Gordaliza, M., Del Olmo, E., Del Corral, M. J. M. (1989): Sesquiterpenoids and phenolics of Pulicaria paludosa. - Phytochemistry 28: 2717-2721. 
[41] Shiraki, K., Masahiko, K., Kumeda, C. A., Yamamura, J-i., Kamiyama, T. (1998): Antipyretic activity of cinnamyl derivatives and related compounds in influenza virusinfected mice. - European Journal of Pharmacology 348: 45-51.

[42] Sindhu, G., Ratheesh, M., Shyni, G. L., Nambisan, B., Helen, A. (2012): Antiinflammatory and antioxidative effects of mucilage of Trigonella foenum graecum (Fenugreek) on adjuvant induced arthritic rats. - International Immunopharmacology 12: 205-211.

[43] Winter, C. A., Risley, F. A., Nuss, O. W. (1962): Carrageenin induced oedema in hand paw of the rat as assays anti-inflammatory drugs. - Proceedings of the Society for Experimental Biology and Medicine 111: 544-547.

[44] Wiseman, S., Mulder, T., Rietveld, A. (2001): Tea flavonoids: bioavailability in vivo and effects on cell signaling pathways in vitro. - Antioxidants and Redox Signaling 3: 10091021.

[45] Zhang, Y., Shu, Z., Yin, L., Ma, L., Wang, X., Fu, X. (2015): Anti-inflammatory and antinociceptive activities of non-alkaloids fractions from Aconitum flavum in vivo. Revista Brasileira Farmacognosia 25: 47-52. 